\section{Ks. Franciszek Jabłoński}

Wyższe Seminarium Duchowne, Gniezno

franusj@wp.pl

DOI: http://dx.doi.org/10.12775/BPTh.2016.001

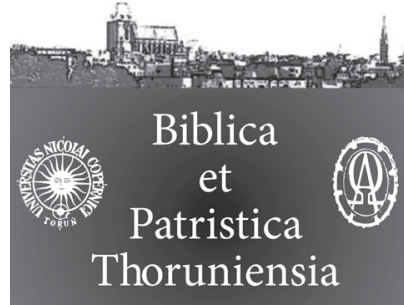

9 (2016) 1: 11-26

ISSN (print) 1689-5150

ISSN (online) 2450-7059

\title{
Tymoteusz wzorem ucznia-misjonarza
}

\section{Timothy - the role model of a missionary disciple}

Streszczenie: W artykule zaprezentowano postać Tymoteusza, jednego z bliskich towarzyszy i współpracowników Apostoła Pawła w dziele ewangelizacji. Na podstawie Nowego Testamentu (Dzieje Apostolskie i listy Pawłowe) przedstawiono jego życie oraz misyjne zaangażowanie. Tymoteusz był sługą Boga w głoszeniu Ewangelii Chrystusa. Istotę jego życia i dzieła wyrażają stosowane w analizowanych źródłach określenia jego osoby: „uczeń” (Dz 16,1); „pomocnik” (Dz 19,22) „brat” (1 Kor 1,1; Kol 1,1; Flm 1,1; 1 Tes 3,2; Hbr 13,23); „umiłowany syn” (1 Kor 4,7; 2 Tm 1,2) „prawowite dziecko w wierze” (1 Tm 1,2); „współpracownik” (Rz 16,21); „sługa Boga i nasz współpracownik” (1 Tes 3,2); „sługa, niewolnik” (Flp 1,1); „sługa Pana” (2 Tm 2,24); „człowiek Boga” (1 Tm 6,11); „nauczyciel” (2 Tm 2,2); „żołnierz” (w 2 Tm 2,3); „zapaśnik” (2 Tm 2,5); „rolnik” (2 Tm 2,6); „pracownik” (2 Tm 2,15); „naczynie” (2 Tm 2,20-21). W ten sposób Tymoteusz stał wzorem do naśladowania dla współczesnych ewangelizatorów.

Abstract: The article features the character of Timothy, one of Paul the Apostle's close companions and co-workers in the work of evangelization. Timothy's life and his missionary involvement is presented on the basis of the New Testament (the Acts of the Apostles and the Pauline epistles). Timothy was a servant of God in preaching the Gospel of Christ. The essence of his life and work is expressed through the terms used in the analyzed sources in reference to him as a person: "disciple" (Acts 16:1); "helper" (Acts 19:22) "brother" (1 Corinthians 1:1; Colossians 1:1; Philemon 1:1; 1 Thessalonians 3:2; Hebrews 13:23); "beloved child" (1 Corinthians 4:7; 2 Timothy 1:2) "true son in the faith" (1 Timothy 1:2); "co-worker" (Romans 16:21); "co-worker in God's service" (1 Thessalonians 3:2); "servant, slave" (Philippians 1:1); "Lord's servant" (2 Timothy 2:24); "man of God" (1 Timothy 6:11); "teacher" (2 Timothy 2:2); "soldier" (2 Timothy 2:3); "athlete" (2 Timothy 2:5); "farmer" (2 Timothy 2:6); "worker" (2 Timothy 2:15); "utensil" (2 Timothy 2:20-21). Thus Timothy became a role model to follow by modern evangelizers.

Słowa kluczowe: Tymoteusz; współpracownik Pawła; ewangelizacja; Dzieje Apostolskie; listy Pawłowe; Paweł; wzór dla współczesnych ewangelizatorów.

Keywords: Timothy; Paul's co-worker; evangelization; Acts of the Apostles; Pauline epistles; Paul; role model for modern evangelizers. 
$\int \mathrm{ez}$ ezusowe polecenie wyrażone w nakazie misyjnym: „Idźcie na cały świat i pozyskujcie uczniów we wszystkich narodach" (Mt 28,19) ${ }^{1}$, zapisane w zakończeniu Pierwszej Ewangelii, pozostaje dla wspólnoty Kościoła zobowiązującym i odpowiedzialnym zadaniem, które wyraźnie określa misję uczniów Jezusa oraz wyznacza jej zasadniczy cel i kierunek. Aby „testament” Jezusa mógł być jak najlepiej zrealizowany, konieczna jest także nieustanna refleksja służąca znalezieniu owocnych sposobów ewangelizacji adekwatnych do wyzwań współczesnego świata.

Papież Franciszek zachęca nas bardzo często do odważnego, ale nade wszystko radosnego głoszenia Ewangelii oraz dzielenia się łaską wiary w Jezusa, Jedynego Zbawiciela świata. W adhortacji Evangelii gaudium przekonuje nas, że „dobrze jest pamiętać o pierwszych chrześcijanach i o tych wszystkich braciach na przestrzeni dziejów, którzy byli pełni radości, pełni niezmordowanej odwagi w głoszeniu Słowa oraz zdolni do wielkiej wytrwałości. Niektórzy się pocieszają, twierdząc, że dzisiaj jest trudniej, jednak musimy przyznać, że okoliczności istniejące w Imperium Rzymskim nie sprzyjały ani głoszeniu Ewangelii, ani walce o sprawiedliwość, ani obronie ludzkiej godności. W każdym momencie dziejów występuje ludzka słabość, chorobliwe poszukiwanie siebie, łatwy egoizm i w końcu pożądliwość zagrażająca wszystkim. Taka rzeczywistość, zawsze obecna pod takim czy innym płaszczykiem, bardziej związana jest z ludzkimi ograniczeniami niż z okolicznościami. A więc nie mówmy, że dzisiaj jest trudniej; jest inaczej. Dlatego uczmy się od świętych, którzy nas poprzedzili i stawili czoło trudnościom występującym w ich epoce"2.

Papież w swoim nauczaniu podkreśla także, że wszyscy na mocy chrztu stajemy się uczniami-misjonarzami, powołanymi, by nieść Ewangelię światu³ „Wszyscy jesteśmy w Kościele uczniami, i jesteśmy nimi zawsze, przez całe życie; i wszyscy jesteśmy misjonarzami, każdy w miejscu, które Pan mu wyznaczył. Wszyscy: nawet najmniejszy jest misjonarzem; a ten, kto wydaje się największy, jest uczniem [...]. My wszyscy jesteśmy uczniami i misjonarzami”4

Podejmując tę papieską zachętę, proponuję refleksję nad współczesną ewangelizacją misyjną na przykładzie doświadczenia Apostoła Pawła oraz jego zaufanego współpracownika, którym był Tymoteusz. Jeden ze współczesnych autorów porównuje dzieło Pawła do biegu (1 Kor 9,26), mającego cztery etapy: najpierw był to maraton, czyli ewangelizacja bez odpoczynku, który często przechodził w bieg z przeszkodami, bo jego misji towarzyszyły niekończące się

1 Cytaty biblijne z Pismo Święte Starego i Nowego Testamentu.

2 Franciszek, Evangelii gaudium, s. 132 (n. 263).

3 Tamże, s. 66 (n. 120).

4 Franciszek, Wszyscy jesteśmy uczniami i misjonarzami. 
problemy, stając się z kolei biegiem sztafetowym w gronie współpracowników, aby ostatecznie być wyścigiem z czasem, przynaglającym do dobrego wykorzystania każdej chwili, by Ewangelia mogła dotrzeć aż po krańce ziemi ${ }^{5}$. Wydaje się zatem bardzo ważne, aby dzieło ewangelizacyjne, które podejmujemy $\mathrm{w}$ różnych wymiarach, było takim swoistego rodzaju biegiem sztafetowym, to znaczy, aby ewangelizator zatroszczył się o grono swoich współpracowników, naśladowców i kontynuatorów. Czytając dzieje Pawła, zauważymy z łatwością, że niemal od samego początku wokół Apostoła gromadzą się ludzie, którzy w rozmaity sposób wspierają go w podejmowanych zadaniach. Wystarczy wspomnieć zakończenie Listu do Rzymian, gdzie Paweł pozdrawia bardzo wiele osób (16,1-16), aż 28 wymienionych z imienia: Feba (16,1), Pryska, Akwila $(16,3)$, Epenet (16,5), Maria (16,6), Andronik, Junia ${ }^{6}(16,7)$, Ampliat $(16,8)$, Urban, Stachys (16,9), Apelles, Arystobul (16,10), Herodion, Narkissos (16,11), Tryfena, Tryfoza, Persida (16,12), Rufus, Jan (16,13, Asynkryt, Flegon, Hermes, Patroba, Hermas (16,14), Filolog, Julia, Nereusz, Olimpas $(16,15)$, ponadto dwie osoby bezimienne: matka Rufusa $(16,13)$, siostra Nereusza $(16,15)$ i pięć grup osób: grupa uczniów, która gromadzi się w domu Pryski i Akwili $(16,5)$, ci z domu Arystobulosa $(16,10)$, ci z domu Narkissosa $(16,11)$, bracia, którzy są z Asynkrytem, Flegonem, Hermesem, Patrobem, Hermasem $(16,14)$ oraz święci, którzy są z Filologiem, Julią, Nereuszem i Olimpasem (16,15). Ta liczna grupa pozdrowionych chrześcijan ${ }^{7}$ wspólnoty rzymskiej ${ }^{8}$ świadczy z jednej strony o jej żywotności, ale także jest dowodem szczególnych związków przyjaźni Pawła z wymienionymi wyżej osobami.

5 Zob. J.H. Prado Flores, Sekret Pawła, s. 115-130.

6 Chodzi tutaj o kobietę o tym imieniu, choć tekst nie jest do końca jasny, zob. J. Gnilka, Paweł z Tarsu. Apostoł i świadek, s. 155 wraz z przypisem 213 oraz E.E. Green, Il vangelo secondo Paolo, s. 159-161.

7 Komentatorzy zwracają uwage, że mamy do czynienia z absolutnym „rekordem” w literaturze antycznej pod względem ilości pozdrowionych osób w zakończeniu listu.

8 Warto w tym miejscu wspomnieć o tak zwanej „hipotezie efeskiej” w odniesieniu do $\mathrm{Rz}$ 16, którego autentyczność, zdaniem niektórych komentatorów, jest problematyczna. W Rz 16 Paweł pozdrawia wiele osób z imienia, co zakłada, że Apostoł zna ich osobiście. Fakt ten zastanawia, gdyż Paweł nie był nigdy w Rzymie. Zwraca się uwagę także na obecność końcowej doksologii w Rz 15,33. Tutaj kończyłby się List wysłany do Rzymu, natomiast rozdział 16 Listu byłby dołączonym „biletem” z pozdrowieniami do wspólnoty w Efezie, kiedy Paweł postanowił i tam wysłać odpis swojego Listu. Stąd w Rz 16 wspomina Akwilę i Pryscyllę, którzy nadal pozostawaliby w Stolicy Azji oraz Epeneta, którego nazywa „pierwocinami złożonymi Chrystusowi przez Azję” (16,5), szczegółowiej problem ten omawia A. Paciorek, Paweł Apostoł, s. 196-198; zob. także A. Pitta, Lettera ai Romani, s. 516-517; S. Légasse, Lépître de Paul aux Romains, s. 946-948. 
Paweł swoich pomocników misji nazywa często współpracownikami. Rze-

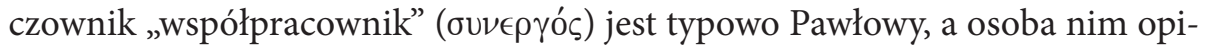
sana posiada trzy charakterystyczne cechy: 1$)$ zadanie, które ma do wykonania pochodzi z wysoka (1 Kor 3,5-9; 2 Kor 1,24; 6,1-4, 1 Tes 3,2); 2) podejmuje powierzoną misję kolegialnie i harmonijnie razem z Pawłem (1 Kor 3,5-9; 15,48; 16,10; 2 Kor 1,26; 6,1; 8,17.23; Flp 2,30, 1 Tes 3,2); 3) angażuje się w konkretną misję głoszenia Ewangelii (1 Kor 3,8-9; 16,15-18; 1 Tes 3,2) ${ }^{9}$. W takim rozumieniu zatem osoba określana mianem „współpracownika” nie była tylko pomocnikiem Pawła w wykonywanej misji, ale angażowała się całkowicie i z oddaniem w służbie Ewangelii i Kościołowi ${ }^{10}$, którą rozumiała jako wyraz służby samemu Bogu (1 Tes 3,2).

Wśród współpracowników Pawła szczególne miejsce zajmuje Tymoteusz, wymieniany sześć razy w Dziejach Apostolskich przez Łukasza (16,1; 17,14.15; $18,5 ; 19,22 ; 20,4)$, aż siedemnaście razy w listach Pawłowych (Rz 16,21; 1 Kor 4,17; 16,10; 2 Kor 1,1.19; Flp 1,1; 2,19; Kol 1,1; 1 Tes 1,1; 3,2.6; 2 Tes 1,1; $1 \mathrm{Tm} 1,2.18 ; 6,20 ; 2 \mathrm{Tm}$ 1,2; Flm 1,1) i ponadto raz wspomniany w Liście do Hebrajczyków $(13,23)$. Papież Benedykt uznał go obok Tytusa za najbliższego współpracownika Apostoła, gdyż „cieszył się on wielkim poważaniem św. Pawła. [...] Apostoł $\mathrm{w}$ istocie powierzał mu ważne misje i widział w nim niemal swoje alter ego, jak wynika z jego wielkiej pochwały tego współpracownika, zawartej w Liście do Filipian: «Nie mam bowiem nikogo równego mu duchem (isópsychon), kto by się szczerze zatroszczył o wasze sprawy» $(2,20)^{\prime 11}$. Niniejszy artykuł składa się z dwóch zasadniczych części. W pierwszej zaprezentuję postać Tymoteusza w świetle Nowego Testamentu ${ }^{12}$, w drugiej natomiast proponuję refleksję nad współpracą w dziele misyjnym Kościoła w oparciu o doświadczenie pierwszych misjonarzy, zwłaszcza Pawła i jego współpracownika Tymoteusza, ukazując go jako wzorzec do naśladowania dla współczesnych ewangelizatorów.

9 Zob. W.-H. Ollrog, Paulus und Seine Mittarbeiter, s. 68-72.

10 Zob. R. Penna, Lettera ai Romani, t. III, Rm 12-16, Bologna 2008, s. 291.

11 Benedykt XVI, Tymoteusz i Tytus.

12 Traktujemy wszystkie kanoniczne listy Pawła jako źródło wiadomości o życiu nie tylko Apostoła, ale także jego towarzyszy. 


\section{Kim był Tymoteusz?}

Paweł poznał prawdopodobnie przyszłego swojego współpracownika i przyjaciela podczas pierwszej podróży misyjnej, którą datujemy na lata $45-46^{13}$. Obejmowała ona Cypr, a następnie tereny Azji Mniejszej (Pamfilię, Likaonię). Po opuszczeniu Ikonium Barnaba i Paweł udali się do Listry i Derbe, aby tam głosić Ewangelię (Dz 14,6). Łukasz opisuje wydarzenie, które miało miejsce w Listrze, kiedy Paweł uzdrowił chorego od urodzenia kalekę. Mieszkańcy miasta uznali misjonarzy za bogów, Barnabę za Zeusa, a Pawła za Hermesa i chcieli im złożyć ofiary. Misjonarze z trudem powstrzymali lud, tłumacząc, że uzdrowienie jest dziełem nie pogańskich bogów, ale Boga żywego (Dz 14,8-18). Choć Dzieje Apostolskie nie wspominają wprost o spotkaniu z Tymoteuszem to jednak jest bardzo prawdopodobne, że właśnie podczas pierwszego pobytu w Listrze Paweł poznał młodego Tymoteusza i jego rodzinę. Jeden ze współczesnych autorów tak wyobraża sobie to spotkanie: „Udało się zachować nic porozumienia między misjonarzami a ludem Likaonii. Niektórzy proszą, żeby im wyjawić tego żywego Boga. Tłumacze czynią swoją powinność. Paweł i Barnaba stopniowo przyswajają sobie podstawowe słownictwo miejscowego dialektu. Mnożą się nawrócenia. Pierwsze dwie kobiety proszą o chrzest: Eunice i jej matka Lois. Następnie przychodzi młody człowiek imieniem Tymoteusz, syn Eunice, prawie dziecko, ale wychowany przez greckiego ojca w języku Peryklesa. Poruszony mową Pawła młodzieniec błaga, by chrześcijanin zabrał go ze sobą. Bądź cierpliwy! - odpowiada Paweł"14. Jest zatem prawdopodobne, że głoszona Ewangelia została przyjęta przez rodzinę Tymoteusza, a także jego samego. Być może Paweł osobiście go ochrzcił, na co mogą wskazywać określenia Apostoła, który nazywa go „swoim umiłowanym synem” (1 Kor 4,17) oraz "prawowitym dzieckiem w wierze" ( 1 Tm 1,2) ${ }^{15}$.

Paweł powrócił do Listry na początku drugiej podróży misyjnej w latach 47-51, kiedy to po rozstaniu się z Barnabą, przybył do Derbe, a następnie Listry (Dz 16,1). Wtedy to po raz pierwszy Łukasz wspomina Tymoteusza z imienia, nazywając go uczniem, co w języku Łukaszowym oznacza chrześcijanina ${ }^{16}$. Taki sposób określenia Tymoteusza może potwierdzać, że przyjął on wiarę i chrzest w imię Jezusa podczas pierwszej podróży misyjnej Pawła. Nosi on imię greckie,

13 Zob. W. Rakocy, Paweł apostoł, s. 81-93. Zaproponowaną przez tego Autora datacją podróży Pawłowych posługuję się w artykule.

14 A. Decaux, Święty Paweł, s. 108.

15 Zob. P. Labuda, Tymoteusz, s. 72.

16 Zob. J.A. Fitzmyer, Gli Atti degli Apostoli, s. 600. 
oznaczające „czczący Boga, bojący się Boga”"17. Jak czytamy w Dziejach, „jego matką była Żydówka, która przyjęła wiarę, a ojcem Grek" $(16,1)$. Informacja ta znajduje swoje potwierdzenie w 2 Tm 1,5-6, gdzie Paweł, zwracając się do Tymoteusza, wspomina „szczerą wiarę, która miała już twoja babka Lois, a następnie twoja matka Eunika ${ }^{18}$. Jestem pewien, że ty także ją posiadasz". Te dwie wzmianki zwracają nasze uwagę na jeszcze jedną bardzo istotną rzecz. Obie kobiety, matka i babka Tymoteusza, wspominane są jako osoby charakteryzujące się mocną i żywą wiarą w Chrystusa, którą przekazały synowi i wnukowi. Według $2 \mathrm{Tm}$ 3,15, Tymoteusz otrzymał także solidną formację religijną, bo od dzieciństwa znał pisma święte, to znaczy Stary Testament, choć nie jest wykluczone odniesienie do istniejących już pism chrześcijańskich ${ }^{19}$.

Tymoteusz pochodził zatem $\mathrm{z}$ rodzimy mieszanej, matka , choć nosiła imię greckie, była Żydówką, zaś ojciec, którego imienia nie znamy, był Grekiem. Po matce zatem Tymoteusz był Żydem ${ }^{20}$. Jego rodzina, a zwłaszcza sam Tymoteusz cieszył się dobrą opinią w Listrze i Ikonium, gdyż bracia, a zatem chrześcijanie z tamtejszych wspólnot „dawali o nim dobre świadectwo” (Dz 16,2). Łukasz informuje także, że Tymoteusz nie był obrzezany ${ }^{21}$ i dlatego Paweł, zabierając go jako towarzysza w swoją podróż misyjną odrzezał go „ze względu na Żydów, którzy mieszkali na tym terenie. Wszyscy bowiem wiedzieli, że jego

17 Zob. P.Cz. Bosak, Słownik - konkordancja, s. 410.

18 W nowym przekładzie Biblii odpowiednik Eunice.

19 Zob. S. Haręzga, Biblia a misja pasterza w Kościele, s. 165-166; J. Wilk, Charakterystyka i zadania, s. 228-231.

20 W. Chrostowski, Był tam pewien uczeń, wyjaśnia: „W starożytności, jak świadczą o tym wzmianki w deuterokanonicznych księgach biblijnych $(\mathrm{Tb} 4,12)$ oraz w piśmiennictwie apokryficznym (3 Ezd 8,68-96; 9,7-9), za większy grzech uważano małżeństwa Żydów z nieżydowskimi kobietami, bo dzieci zrodzone w takich związkach nie były Żydami. Natomiast małżeństwa Żydówek z nie-Żydami, zwłaszcza zamożniejszymi i wpływowymi, traktowano o wiele bardziej ulgowo. Było tak dlatego, że ich dzieci nadal pozostawały - po matce - Żydami. W diasporze takie małżeństwa były nawet dość częste, przyczyniając się do liczebnego wzrostu populacji żydowskiej i uszczuplania populacji nieżydowskiej, gdyż ta «traciła» mężczyznę, a wraz z nim dzieci, które miał spłodzić. Tymoteusz, syn Greka, był więc Żydem po swojej matce".

21 „Jeśli traktować imiona jako odzwierciedlenie środowiska i otoczenia, w jakim rodzą się i wzrastają ci, którzy je noszą, Eunice wywodziła się z zasymilowanej rodziny żydowskiej, a rodzice dali jej imię, jakie nosiły dziewczęta nieżydowskie. Bardzo prawdopodobne, że ona, jak być może jej najbliższa rodzina, nie przestrzegała skrupulatnie Tory, za czym przemawia fakt, że Tymoteusz nie został obrzezany. A może decydujący głos w tych kwestiach należał do ojca, ten zaś, jako Grek, nie dopuścił do "okaleczenia” chłopca, bo właśnie tak Grecy patrzyli na obrzezanie”, W. Chrostowski, Był tam pewien uczeń. 
ojciec był Grekiem” (Dz 16,3-4). W ten sposób Tymoteusz stał się współpracownikiem Pawła w głoszeniu Ewangelii Jezusowej.

\section{Tymoteusz: misyjne zaangażowanie}

Młody i pełen gorliwości Tymoteusz od razu angażuje się w misje Pawła. Rusza razem z nim z Listry, aby towarzyszyć Apostołowi w jego dalszych etapach drugiej podróży misyjnej, najpierw w Azji Mniejszej, a potem w Macedonii, gdzie przez Amfipolis i Apolonię dotarli do Tesalonik (Dz 17,1, gdzie Tymoteusz i Sylas pozostali jakiś czas (Dz 17,14), podczas gdy Paweł udał się w kierunku morza, a następnie w towarzystwie chrześcijan z Berei do Aten. Sylas i Tymoteusz zostali wezwani, aby dołączyć do Pawła $(\mathrm{Dz} 17,15)$, a następnie towarzyszyli Pawłowi w Koryncie (18,5; 2 Kor 1,19). Zaniepokojony wieściami z Tesalonik Paweł posłał Tymoteusza, prawdopodobnie z Aten, o czym świadczy wzmianka w pierwszym liście, napisanym przez Apostoła do wspólnoty w Tesalonikach: „posłaliśmy do was Tymoteusza, naszego brata i współpracownika w głoszeniu Ewangelii Chrystusa. On miał was umocnić i zachęcić do wytrwania w wierze, aby nikt się nie załamał z powodu utrapień" (1 Tes 3,2-3). Tymoteusz wywiązał się ze zleconej mu zadania i powrócił do Pawła z dobrymi wiadomościami: „Teraz właśnie Tymoteusz wrócił od was i przyniósł dobre wieści o waszej wierze i miłości, o tym ,że zawsze dobrze o nas myślicie i podobnie jak my pragniecie nas zobaczyć" (1 Tes 3,6$)$. Te pozytywne informacje napełniły Pawła radością i nadzieją. Po pobycie w Koryncie, Paweł przez Efez i Cezareę udał się do Jerozolimy, a następnie do Antiochii (Dz 18,21-22).

Tymoteusza spotykamy ponownie podczas trzeciej podróży misyjnej w latach 52-56. Był przy Apostole w Efezie, skąd prawdopodobnie Apostoł pisał do Filemona oraz do Filipian. W obydwu listach Tymoteusz występuje jako jeden z nadawców (Flm 1; Flp 1,1). Z Efezu Paweł wysłał go do Macedonii wraz z niejakim Erastem (Dz 19, 22), a potem również do Koryntu. Zgodnie z informacjami w 1 Kor 4,17 został posłany przez Pawła do Koryntu. Apostołowi zależało bardzo, aby przypomnieć Koryntianom nauczanie głoszone przez Pawła w Koryncie, które zrodziło ich do wiary w Jezusa: „Choćbyście mieli dziesiątki tysięcy wychowawców w Chrystusie, ojców macie niewielu, a właśnie ja w Chrystusie Jezusie zrodziłem was przez Ewangelię. Dlatego zachęcam was; bądźcie moimi naśladowcami!. W tym celu posłałem do was Tymoteusza, który jest moim ukochanym i wiernym Panu dzieckiem, aby wam przypomniał moje drogi w Chrystusie Jezusie, jak nauczam w każdym Kościele" (1 Kor 4,15-17). Paweł polecił jednocześnie Tymoteusza trosce wspólnoty: „Gdy przybędzie Tymoteusz, to uważajcie, by mógł przebywać wśród was bez obaw. Przecież on tak 
samo jak ja pracuje dla sprawy Pana. Niech go nikt nie lekceważy. Odeślijcie go w pokoju, aby dotarł do mnie. Czekam na niego wraz z braćmi” (1 Kor 16,10-11).

Nasz bohater występuje również w Drugim Liście do Koryntian jako jeden z nadawców (2 Kor 1,1), a kiedy Paweł pisze z Koryntu List do Rzymian, załącza w nim - obok pozdrowień od innych, również od Tymoteusza: „pozdrawia was Tymoteusz, mój współpracownik i moi rodacy; Lucjusz, Jazon i Sozypater" (Rz 16,21).

Z Koryntu wraz z innymi uczniami Tymoteusz wyruszył do Troady, położonej na azjatyckim wybrzeżu Morza Egejskiego, i tam czekał na Pawła zdążającego do Jerozolimy pod koniec trzeciej wyprawy misyjnej (Dz 20,4). Dalsze losy Tymoteusza pozostają mniej znane. Na podstawie wzmianek z listów więziennych (Flp ${ }^{22}$ 1,1; 2,19-22; Flm 1,1; Kol 1,1) był razem z Pawłem w czasie jego pierwszego więzienia rzymskiego (59-61 r.). Przyjmując tradycyjne dane $e^{23}$ po zwolnieniu $\mathrm{z}$ więzienia w Rzymie Paweł odbył podróż na Wschód, podczas której ustanowił Tymoteusza biskupem Efezu (1 Tm 1,1-4; 18-19; 3,14-14; 4,12-16; 5,19-20.22; 6,20-21; 2 Tm 1,1-8; 2,22-23; 3,10-11.14). Kiedy znalazł się ponownie $\mathrm{w}$ Rzymie pisał $\mathrm{z}$ więzienia, prosząc, aby Tymoteusz przybył do stolicy imperium, zabierając ze sobą Marka oraz przynosząc Pawłowi pozostawiony w Troadzie płaszcz oraz pergaminy (2 Tm 4,6.9.11.13). Ostatnia wzmianka pochodzi z Hbr 13,23, gdzie mowa o uwolnieniu Tymoteusza, nie wiadomo jednak, o jakie więzienie mogłoby chodzić. Zdaniem A. Troniny, użyty czasownik $\dot{\alpha} \pi 0 \lambda \cup ́ \omega$ „nie musi oznaczać, że Tymoteusz był uwięziony. Równie dobrze może oznaczać wysłanie na misję, jak niegdyś Barnabę i Szawła wysłała gmina Antiocheńska na Cypr"24.

Zgodnie z tradycją po śmierci Pawła Tymoteusz był biskupem Efezu, co potwierdza także Euzebiusz ${ }^{25}$ i zakończył życie w ostatnich latach pierwszego wieku. Według apokryficznych Dziejów Tymoteusza, poniósł śmierć męczeńską za czasów Nerwy (96-98), około roku $97^{26}$.

22 Według tradycyjnego ujęcia List do Filipian powstał podczas pierwszego więzienia rzymskiego. Obecnie wielu egzegetów uważa, że został napisany wcześniej podczas uwięzienia Pawła w Efezie w czasie trzeciej podróży misyjnej, zob. W. Rakocy, Paweł apostoł, s. 182-203.

23 Zob. P.Cz. Bosak, Słownik - konkordancja, s. 413-414.

24 A. Tronina, Do Hebrajczyków, s. 173-174.

25 Euzebiusz z Cezarei, Historia Kościelna, s. 94.

26 Zob. P.Cz. Bosak, Słownik - konkordancja, s. 411. 


\section{Tymoteusz: sługa Boga w głoszeniu Ewangelii Chrystusa}

Zadania, a nawet szerzej misję Tymoteusza, wyrażają różnego rodzaju tytuły czy określenia, które zostały mu nadane przez samego Pawła czy Łukasza w Dziejach Apostolskich i pojawiają się obok jego imienia ${ }^{27}$. Warto zatem prześledzić te najważniejsze. Zaczynamy od dzieła Łukaszowego.

W Dz 16,1, kiedy to Łukasz po raz pierwszy wymienia imię Tymoteusza, nazwał go „uczniem” ( $\mu \alpha \theta \eta \tau \eta ́$ s). Jak to już zostało wspomniane wcześniej, to typowo Łukaszowe określenie wskazuje jednoznacznie na wyznawcę Jezusa (Dz 6,1.2.7; 9,1.10.19.25.26bis.38; 11,26.29; 13,52; 14,20.22.28; 15,10; 18,23.27; 19,1.9.30; 20,1.30; 21,4.16bis) ${ }^{28}$. Dzięki głoszonej przez Pawła Ewangelii, już prawdopodobnie podczas pierwszego pobytu w Listrze, stał się wyznawcą i uczniem Tego, którego uznał za Boga żywego i Mesjasza Izraela. Powołany przez Pawła do misji ewangelizacyjnej ruszył ochoczo w nieznane, aby Dobrą Nowinę zanieść razem z Apostołem aż po najdalsze krańce świata. Ponieważ autor Dziejów Apostolskich opowiada nam o rozszerzaniu się Ewangelii, zwłaszcza jako owocu ewangelizacyjnych wysiłków Pawła, czterokrotnie wspomina nam jeszcze Tymoteusza jako towarzysza podróży Apostoła $(17,14.15$; $18,5 ; 20,4)$. Zwłaszcza ostatni tekst, poprzez użycie czasownika $\sigma u v^{\prime} \pi$ то $\mu \alpha \iota$, podkreśla czynny udział Tymoteusza w podróży Pawła. Jeden raz natomiast Łukasz nazywa Tymoteusza „pomocnikiem” w 19,22: „Wysłał do Macedonii dwóch

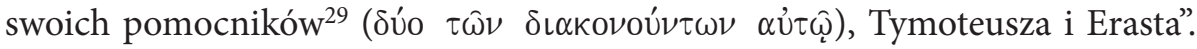
Dosłownie oznacza to dwóch z tych, którzy mu służyli, a zatem sługi Pawła. Mamy zatem wyrażoną ideę służby i zależności Tymoteusza od Apostoła. Jeżeli wspomnianego tutaj Erasta uznamy za tę samą osobę, która jest wzmiankowana w Rz 16,24 oraz $2 \mathrm{Tm} 4,20$, to ponieważ był skarbnikiem miasta Koryntu (Rz 16,24), może właśnie jemu i Tymoteuszowi Paweł zlecił przeprowadzenie kolekty dla wspólnoty w Jerozolimie ${ }^{30}$.

Kolejne określenie Tymoteusza, które wskazuje na przynależność do Chrystusa i wspólnoty Kościoła to rzeczownik „brat” ( $\alpha \delta \in \lambda \phi o ́ \varsigma)$, zastosowany pięć razy: trzykrotnie w adresach listów (1 Kor 1,1; Kol 1,1; Flm 1,1), jeden raz w 1

27 Tylko w 1 Tes 1,1 oraz 2 Tm 1,1 występuje samo imię Tymoteusza bez żadnego określenia.

28 Zob. J.A. Fitzmyer, Gli Atti degli Apostoli, s. 345-346.

29 Tutaj pozostaję przy tłumaczeniu Biblii Tysiąclecia: Pismo Święte Starego i Nowego Testamentu w przekładzie z języków oryginalnych. Biblia Paulistów tłumaczy „dwóch współpracowników".

30 Zob. R. Pesch, Atti degli Apostoli, s. 738-739. 
Tes 3,2, gdzie Paweł wspomina o posłaniu „Tymoteusza, naszego brata” do wspólnoty w Tesalonikach oraz jeden raz poza Corpus Paulinum w Hbr 13,23, gdzie mowa o zwolnieniu (posłaniu) Tymoteusza. Termin „brat” nie oznacza tutaj oczywiście braterstwa krwi, ale jest używany w sensie Łk 8,19-21, gdzie mowa o nowej rodzinie Jezusa, w której nie liczy się pokrewieństwo, ale przynależą do niej ci wszyscy, którzy „słuchają słowa Bożego i wprowadzają je w czyn" $(Ł k$ 8,21). Termin ten zatem wskazuje na przynależność do widzialnej wspólnoty zbawienia, gdzie Chrystus jest przyczyną i celem braterstwa, a jego treścią i manifestacją jest miłość ${ }^{31}$.

O bliskiej bardzo relacji Pawła i Tymoteusza świadczy używane przez Apo-

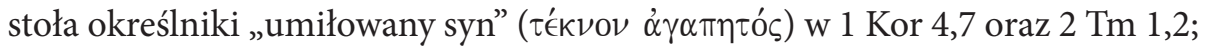

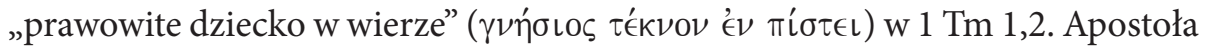
traktował Tymoteusza niemal jako swojego syna, zrodzonego dla wiary w Jezusa dzięki przepowiadanej Ewangelii. Ta myśl o rodzeniu dla wiary przez przepowiadanie Ewangelii była bliska Apostołowi, czego daje wyraz w 1 Kor 4,15. W 1 Tm 1,18-19, kiedy Apostoł zwracał się do Tymoteusza nazywał go „swoim dzieckiem", a następnie dał polecenia, aby prowadził bój, zachowując wiarę i prawe sumienie. Natomiast w Flp 2,22 Apostoł, mając na uwadze, że Tymoteusz rozumie Pawła i troszczy się o chrześcijan, wyraźnie stwierdził, że „wiecie zresztą, że można na nim polegać, gdyż służył mi jak dziecko ojcu w szerzeniu Ewangelii”. Powyższe teksty jednoznacznie potwierdzają, że chodzi o więź między Pawłem a Tymoteuszem, która była owocem wspólnie przezywanej wiary w Jezusa oraz jednoczącego ich dzieła ewangelizacji.

Z przyjętej wiary w Chrystusa wypływa także szczere i całkowite zaangażowanie misyjne Tymoteusza. Wskazują na to kolejne określenia. W Rz 16,21 Pa-

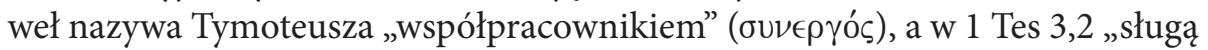

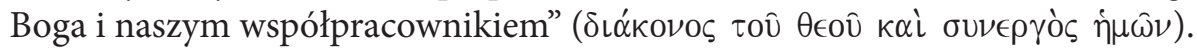

Myśl o służbie i całkowitym oddaniu Ewangelii Chrystusowej potwierdza dodatkowo zastosowany w odniesieniu do Tymoteusza rzeczownik „sługa,

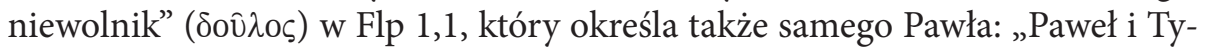
moteusz, słudzy Chrystusa”. Jak stwierdza J. Flis: «Paweł i Tymoteusz jako niewolnicy służą całkowicie Chrystusowi Jezusowi, gdyż to On ich wykupił z dotychczasowej niewoli. Teraz Jezus jest jedynym Panem nie tylko dla nich jako odkupionych (uwolnionych), ale i dla wszystkich chrześcijan. Stąd Paweł pisze w 1 Kor 7,23: „Za wielką bowiem cenę zostaliście nabyci. Nie bądźcie więc niewolnikami ludzi” (Rz 6,17-18; por. Rz 6,6-11; Ga 1,30; 3,13; Kol 3,22-24)» ${ }^{32}$. Ponadto $\mathrm{w} 2 \mathrm{Tm}$ 2,24, zwracając się z pouczeniami do Tymoteusza, nazywa go

\footnotetext{
31 Zob. J. Flis, List do Filipian, s. 384.

32 J. Flis, List do Filipian, s. 78.
} 


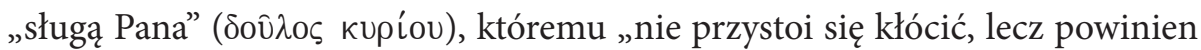
być życzliwy dla wszystkich, umiejętnie pouczać i cierpliwie znosić przeciwności”. Zatem sformułowanie to „określa relację do Boga, a zarazem eksponuje uległość wobec Jego woli. Ustala także odniesienie wobec społeczności i poszczególnych osób. Ten, kto pełni funkcję przełożonego, nie jest ani panem, ani właścicielem wspólnoty, której przewodzi. Jest jej sługą, który swoją osobowością i stylem postępowania wyraźnie odróżnia się od fałszywych nauczycieli, naruszających czystość przekazu Ewangelii oraz rozbijających jedność chrześcijańskich wspólnot"33.

Pozostałe informacje, które odnajdujemy w tekstach obok imienia Tymoteusza wskazują również na jego misję i powierzone mu zadania. Najpierw w 1 Kor 16,10, gdy Paweł rekomenduje Tymoteusza wspólnocie w Koryncie, stwierdza, że „on tak samo jak ja pracuje dla sprawy Pana”. Według 2 Kor 2,19 jest głosicielem, obok Pawła i Sylwana, Syna Bożego, Jezusa Chrystusa, zaś w Flp 2,19 jest posłańcem Pawła Filippi, który ma poinformować Apostoła o życiu wspólnoty. Podobnie posłany do Tesalonik, przynosi Pawłowi dobre wieści o tamtejszych chrześcijanach $(1$ Tes 3,6$)$. Jemu także Apostoła nakazuje strzec depozytu nauki wiary (1 Tm 6,20). Te wszystkie elementy świadczą wymownie, że Tymoteusz zaangażował się w dzieło głoszenia Ewangelii, wspierając Apostoła Pawła. Jednocześnie cieszył się jego uznaniem, zaufaniem i całkowicie zasłużył na miano współpracownika Pawła i sługi samego Chrystusa.

Na koniec warto jeszcze wspomnieć o innych tytułach Tymoteusza, które pojawiają się Listach Pasterskich, choć nie bezpośrednio przy jego imieniu. Je-

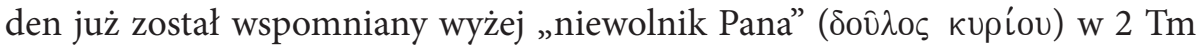
2,24. Pozostałe siedem, na które warto zwrócić uwagę, są następujące: „człowiek

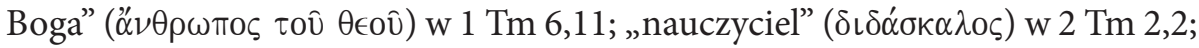

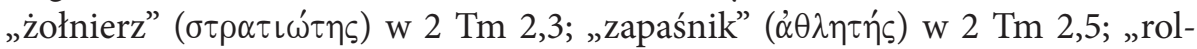

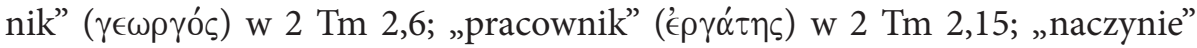

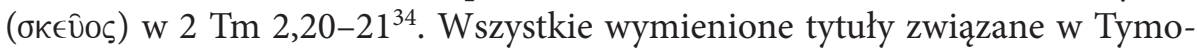
teuszem wskazują przede wszystkim na konieczność więzi z Bogiem, bo tylko w tej relacji Tymoteusz jako głosiciel Ewangelii i przełożony wspólnoty może oddziaływać na innych ludzi i wiernie wykonywać zlecone mu zadana ewangelizacyjne i pasterskie. Jednocześnie podkreślają konieczność wytrwałości i cierpliwości w podjętej misji, co w praktyce oznacza systematyczną i długotrwałą pracę, odpowiedzialne posługiwanie na rzecz zleconego dzieła. Tylko taka postawa gwarantuje ewangeliczny sukces, obfity plon, a Tymoteuszowi

33 J. Wilk, Charakterystyka i zadania przełożonego, s. 205.

34 Szczegółowe omówienie wszystkich tytułów, zob. J. Wilk, Charakterystyka i zadania przełożonego, s. 156-208. 
daje możliwość pełnego i owocnego bardzo udziału w trudach i cierpieniach znoszonych dla Ewangelii, ufając mocy Boga (2 Tm 1,8).

\section{Tymoteusz: wzór zaangażowania w dzieło ewangelizacji misyjnej}

Parafrazując zachętę Apostoła Pawła, skierowaną do braci w Filippi, aby go naśladowali i patrzyli na tych, którzy postępują według jego przykładu (Flp 3,17; także 1 Kor 4,16;11,1), stawiamy pytanie o aktualność doświadczenia Tymoteusza dla nas współczesnych wyznawców Jezusa, tak samo odpowiedzialnych za Ewangelię Chrystusową w dzisiejszym świecie. Zastanawiając się nad jego życiem i działalnością bez wątpienia można powiedzieć, że jest on godnym naśladowania „ewangelizatorem z Duchem”35.

Najpierw otrzymał od Chrystusa łaskę spotkania z autentycznym chrześcijańskim świadectwem przyniesionym przez samego Apostoła Pawła. Jego gorliwość misyjna oraz świadectwo Ewangelii, którą głosił z zapałem, pociągnęła także młodego Tymoteusza. Paweł bowiem osobiście doświadczył łaski Bożej i spotkał Tego, którego przepowiadał. Nie był sprawozdawcą tego, co powiedzieli inni, ale wiarygodnym świadkiem i przekonywającym nauczycielem. To ewangeliczne ziarno przyniesione przez Pawła padło także do dobrą glebę, używając porównania z przypowieści Jezusowej (Mt 13,3-8; Mk 4,1-9; Łk 8,4-8). Tą urodzajną rolą nie było tylko serce Tymoteusza, ale także jego najbliższa rodzina - matka i babcia. Kobiety te nie tylko zadbały o jego wychowanie religijne, ale także stały się współwyznawcami Chrystusa i z pewnością wspierały swojego syna i wnuka w odkrywaniu piękna nowej wiary w Jezusa z Nazaretu, Mesjasza Izraela i Syna Bożego.

Każdy człowiek, aby dobrze wypełnić powierzoną mu misję, musi znaleźć odpowiednią motywację. Tak jest także w przypadku ucznia-misjonarza, dla którego motywacją zaangażowania jest miłość Jezusa, którą przyjął. Niezwykle ważne jest zatem, aby on sam miał tego głęboką świadomość, ale nie teoretyczną. Chodzi o doświadczenie bycia umiłowanym, co ostatecznie znaczy zbawionym przez Jezusa. To miłość Chrystusa do człowieka i człowieka do Niego pozostaje motywem wszelkiej misji ewangelizacyjnej. Pyta papież Franciszek: „Lecz cóż to za miłość, która nie odczuwa potrzeby mówienia o ukochanej istocie, ukazywania jej, starania się, by inni ją poznali?"36. Tymoteusz odkrył Miłość Boga w Jezusie i pragnął podzielić się tą dobrą wiadomością z innymi.

\footnotetext{
35 Zob. Franciszek, Evangelii gaudium, s. 131 (n. 262).

36 Franciszek, Evangelii gaudium, s. 132 (n. 264).
} 
To motywowało go nie tylko do naśladowania Apostoła Pawła, ale wyzwalało w nim niezwykły zapał ewangelizacyjny, bo głęboko pragnął, aby i inni ludzie odkryli tę radosną prawdę. Powyższe przekonanie motywowało go do podejmowania trudów ewangelizacyjnych. Nie zniechęcały go niepowodzenia, przeszkody, młody wiek, słabe zdrowie, czy innego rodzaju napotykane trudności. Pracę do Jezusa i Jego Ewangelii traktował jako zaszczytną służbę, pamiętając słowa Pawła: „Głoszę bowiem Ewangelię nie dla własnej chluby, ale z nałożonego na mnie obowiązku. Biada mi, gdybym nie głosił Ewangelii!” (1 Kor 9,16). Taka właśnie postawa to „mentalność ewangelizacyjna”, która winna cechować ucznia-misjonarza każdego czasu.

Uczeń-misjonarz Chrystusa potrzebuje formacji ewangelizacyjnej, której celem jest przekazanie wiary, ale przede wszystkim ukształtowanie w człowieku swoistego rodzaju „mentalności ewangelizacyjnej”, aby jego „serce biło dla ewangelizacji, pasją w ewangelizowaniu i było ogarnięte obsesją Ewangelii”" ${ }^{37}$. Taka formacja jest możliwa, kiedy spotyka się prawdziwego świadka Jezusa, gdzie słowo Boże wyraża się przede wszystkim w świadectwie chrześcijańskiego życia. Przypomniał nam o tym papież Benedykt: «Ważne jest jednak, by w każdej formie przepowiadania pamiętano przede wszystkim o wewnętrznym związku między przekazywaniem Słowa i świadectwem chrześcijańskim. Od tego uzależniona jest sama wiarygodność tego, co się głosi. Z jednej strony konieczne jest słowo, które przekazuje to, co sam Pan nam powiedział. Z drugiej nieodzowne jest nadanie temu słowu wiarygodności, by nie jawiło się jako piękna filozofia lub utopia, ale jako rzeczywistość, którą można żyć i dzięki której można żyć. Ta wzajemna zależność słowa i świadectwa nawiązuje do sposobu, w który Bóg przemówił przez wcielenie swego Słowa. Słowo Boże dociera do ludzi „przez spotkanie ze świadkami, dzięki którym staje się obecne i żywe"38. Każdemu człowiekowi, szczególnie nowym pokoleniom, potrzebne jest bowiem wprowadzenie w słowo Boże „dzięki spotkaniu z dorosłym i jego autentycznemu świadectwu, pozytywnemu wpływowi przyjaciół i towarzyszeniu wielkiej wspólnoty kościelnej”. Istnieje ścisły związek między świadectwem Pisma jako zapisem tego, co Słowo Boże mówi o sobie, a świadectwem życia wierzących. Jedno zakłada drugie i do niego prowadzi. Świadectwo chrześcijańskie przekazuje Słowo, o którym mówią Pisma. Pisma z kolei objaśniają świadectwo, które, dawane własnym życiem, stanowi powołanie chrześcijan. W ten sposób ci, którzy spotykają wiarygodnych świadków Ewangelii, przekonują się o skuteczności słowa Bożego w tych, którzy je przyjmują» ${ }^{39}$.

37 J.H. Prado Flores, Sekret Pawła, s. 126.

38 Benedykt XVI, Verbum Domini, s. 104-105 (n. 97).

39 Tamże, s. 104-105 (n. 97). 
Zaangażowanie Tymoteusza wynikało z jego głębokiego przekonania, że głosząc Ewangelię, niesie światu jedyną prawdę o Bogu i człowieku, która jest zdolna odpowiedzieć „na najgłębsze potrzeby osób, ponieważ wszyscy zostaliśmy stworzeni do tego co proponuje nam Ewangelia: do przyjaźni z Jezusem i miłości braterskiej" ${ }^{40}$. Jeśli zatem Ewangelia Jezusowa jest prawdą, to trzeba ją głosić, ale także strzec przez manipulacjami czy wręcz sfałszowanie. Ma tego świadomość Apostoł, kiedy zachęca Tymoteusza, aby strzegł depozytu wiary (1 Tm 6,2; 2 Tm 1,14) i zdrowej nauki (2 Tm 4,2), którą otrzymał i przekazuje dalej. Temu celowi służy przede wszystkim solidna formacja przyszłych ewangelizatorów i formatorów, która powinna opierać się na zażyłej relacji z Jezusem i Jego wspólnotą. Potrzebna jest także poznanie „depozytu wiary” poprzez rzetelne studium Słowa Bożego. Paweł chwalił swojego współpracownika, że od młodzieńczych lat zna Pisma. To właśnie w modlitewnym spotkaniu ze Słowem Bożym oraz pogłębionym jego studium ewangelizatorzy znajdują umocnienie swojej wiary, nieustannie odnawiają siły i zapał ewangelizacyjny oraz przygotowują się do kompetentnego i przekonywającego głoszenia Chrystusowej Ewangelii, co jest tak często postulowane także w kontekście nowej ewangelizacji: «Papież Jan Paweł II, nawiązując do tego, co wyraził już papież Paweł VI w adhortacji apostolskiej Evangelii nuntiandi, na różne sposoby napominał wiernych, że konieczna jest nowa epoka misyjna, angażująca cały lud Boży. U progu trzeciego tysiąclecia nie tylko istnieją liczne ludy, które jeszcze nie poznały Dobrej Nowiny, ale wielu chrześcijan potrzebuje, aby na nowo głoszono im z przekonaniem słowo Boże, by mogli konkretnie doświadczyć mocy Ewangelii. Tylu jest braci „ochrzczonych, ale niewystarczająco zewangelizowanych". Często kraje niegdyś bogate w wiarę i powołania tracą swoją tożsamość pod wpływem kultury zeświecczonej. O potrzebie nowej ewangelizacji, tak bardzo odczuwanej przez mojego czcigodnego poprzednika, o skuteczności słowa Bożego należy mówić na nowo bez lęku, z przekonaniem. Kościół, pewny wierności swego Pana, niezmordowanie głosi dobrą nowinę Ewangelii i zachęca wszystkich chrześcijan do ponownego odkrycia, jak fascynujące jest naśladowanie Chrystusa» ${ }^{41}$.

Papież Franciszek przypomina nam także, że prawdziwy „ewangelizator z Ducha” odczuwa "duchową przyjemność bycia Ludem Bożym” 42 , z czego rodzi się potrzeba i pragnienie bycia $z$ Ludem Bożym. To było także doświadczeniem Tymoteusza, który wraz z Pawłem zakładał wspólnoty, powracał do nich, aby umacniać ich wiarę, aż w końcu sam stanął na czele wspólnoty w Efezie. Był

\footnotetext{
40 Franciszek, Evangelii gaudium, s. 133 (n. 265).

41 Benedykt XVI, Verbum Domini, s. 103-104 (n. 96).

42 Franciszek, Evangelii gaudium, s. 135 (n. 268).
} 
dla drugiego człowieka. Nie bał się świata, choć czasami ten okazywał się nieprzyjazny i wrogo nastawiony. Nie obrażał się na świat, że niekiedy nie chciał słuchać i przyjmować ewangelicznej prawdy. To jeszcze bardziej wyzwalało gorliwość apostolską, aby głosić słowo, nalegać w porę i nie w porę, upominać, karcić i zachęcać, nauczać $\mathrm{z}$ wielką cierpliwością ( 2 Tm 4,2). W ten sposób był z drugim człowiekiem i dla drugiego, a Ewangelia przez Niego głoszona mogła docierać do wielu. Taka postawa jest także naśladowaniem samego Jezusa. Papież Franciszek pisze o tym wprost: „Zafascynowani takim wzorem, integrujmy się dogłębnie ze społeczeństwem, dzielmy życie ze wszystkimi, wsłuchujmy się w ich troski, współpracujmy materialnie i duchowo w ich potrzebach, radujmy się z tymi, którzy przeżywają radość, płaczmy z tymi, którzy płaczą, i angażujmy się w budowę nowego świata, ramię w ramię z innymi"43. Tylko w taki sposób ewangelizator Jezus zmartwychwstały będzie nie tylko obecny w świecie, ale nadal będzie mógł działać i okazywać swoje miłosierdzie człowiekowi.

$\mathrm{Na}$ koniec warto zwrócić uwagę na jeszcze jeden ważny aspekt zaangażowania misyjnego Tymoteusza. Potrafił on współpracować z Pawłem i innymi, na przykład z Sylasem, w dziele ewangelizacji. Był gotowy i dyspozycyjny dla wielu form współdziałania dla Ewangelii, które jednocześnie uważał za służbę Kościołowi. Zdaniem Benedykta XVI: „Źródła dotyczące Tymoteusza i Tytusa wyraźnie ukazują ich gotowość do podejmowania różnych zadań, polegających często na reprezentowaniu Pawła, także w niełatwych sytuacjach. Jednym słowem, uczą nas oni służyć ofiarnie Ewangelii, ze świadomością, że oznacza to również służbę samemu Kościołowi" ${ }^{44}$. Potrzeba także i dzisiaj formowania do takiej postawy oraz nieustannego poszukiwania nowych form współpracy w misji ewangelizacji, aby Dobra Nowina mogła się rozszerzać i owocować w naszym życiu. Nadal przecież pozostaje w mocy zobowiązujący „testament” Jezusa: „staniecie się moimi świadkami w Jerozolimie, w całej Judei, w Samarii i aż po krańce ziemi” (Dz 1,8).

\section{Bibliografia}

Benedykt XVI, Tymoteusz i Tytus - najbliżsi współpracownicy Pawła, Audiencja generalna, 13 grudnia 2006, http://www.opoka.org.pl/biblioteka/W/WP/benedykt_ xvi/audiencje/ag_13122006.html[dostęp: 30.01.2016].

Benedykt XVI, Verbum Domini. O Słowie Bożym w życiu i misji Kościoła, Kraków 2010. Bosak P.Cz., Słownik - konkordancja osób Nowego Testamentu, Poznań 1991. 
Chrostowski W., Był tam pewien uczeń imieniem Tymoteusz (Dz 16,1), http://adonai.pl/ czytania/?id=110 [dostęp: 30.01.2016].

Decaux A., Święty Paweł, Warszawa 2006.

Euzebiusz z Cezarei, Historia Kościelna. O Męczennikach Palestyńskich, (tłum. A. Lisiecki), Poznań 1924.

Fitzmyer J.A., Gli Atti degli Apostoli. Introduzione e commento, Brescia 2003.

Flis J., List do Filipian, Częstochowa 2011.

Franciszek, Evangelii gaudium. O głoszeniu Ewangelii $w$ dzisiejszym świecie, Kraków [b.r.w.].

Franciszek, Wszyscy jesteśmy uczniami i misjonarzami. Audiencja generalna. 15 stycznia 2014, http://www.opoka.org.pl/biblioteka/W/WP/franciszek_i/audiencje/ ag_15012014.html [dostęp: 07.02.2016].

Gnilka J., Paweł $z$ Tarsu. Apostoł $i$ świadek, Kraków 2001.

Green E.E., Il vangelo secondo Paolo. Spunti per una lettura al femminile (e non solo), Torino 2009.

Haręzga S., Biblia a misja pasterza w Kościele według Pierwszego i Drugiego Listu do Tymoteusza oraz Listu do Tytusa, w: W. Chrostowski (red.), Przybliżyło się Królestwo Boże. Księga pamiątkowa dla Księdza Profesora Romana Bartnickiego w 65. rocznice urodzin, Warszawa 2008, s.161-173.

Labuda P., Tymoteusz - najblizszy i umiłowany uczeń św. Pawła, „Katecheta” 52 (2008)11, s. 71-73.

Légasse S., Lépître de Paul aux Romains, Paris 2002.

Ollrog W.-H., Paulus und Seine Mittarbeiter. Untersuchungen zu Theorie und Praxis der paulinischen Mission, Neukirchen-Vluyn 1979.

Paciorek A., Paweł Apostoł - Pisma, cz. I, Tarnów ${ }^{2} 1997$.

Penna R., Lettera ai Romani, t. III, Rm 12-16, Bologna 2008.

Pesch R., Atti degli Apostoli, Assisi 1992.

Pismo Święte Starego i Nowego Testamentu w przekładzie z języków oryginalnych. Opracował zespół biblistów polskich z inicjatywy Benedyktynów Tynieckich, (Biblia Tysiąclecia), Poznań ${ }^{3} 1982$.

Pismo Święte Starego i Nowego Testamentu. Najnowszy przekład z języków oryginalnych z komentarzem. Opracował Zespół Biblistów Polskich z inicjatywy Towarzystwa Świętego Pawła, Częstochowa 2008.

Pitta A., Lettera ai Romani, Milano ${ }^{2} 2001$.

Prado Flores J.H., Sekret Pawła, Łódź 2007.

Rakocy W., Paweł apostoł. Chronologia życia i pism, Częstochowa 2003.

Tronina A., Do Hebrajczyków. Słowo zachęty na dni ostatnie, Częstochowa 1998.

Wilk J., Charakterystyka i zadania przełożonego wspólnoty chrześcijańskiej według Listów Pasterskich. Studium biblijno-pragmatyczne, Katowice 2015. 